\title{
DISSECTING THE OPAQUE-2 REGULATORY NETWORK USING TRANSCRIPTOME AND PROTEOME APPROACHES ALONG WITH ENZYME ACTIVITY MEASUREMENTS
}

\author{
Agnès Lefèvre"; Luciano Consoli; Salete A. Gaziola3; Ana Paula Pellegrino³; Ricardo A. \\ Azevedo $^{3}$; Catherine Damerval ${ }^{2 *}$ \\ ${ }^{1}$ INRA-URGV Unité de Recherche en Génomique Végétale, 2 rue Gaston \\ Crémieux 91057 EVRY Cedex \\ ${ }^{2}$ Station de Génétique Végétale, UMR 320 UPS/INA-PG/INRA, Ferme du Moulon 91190 Gif-sur-Yvette, France \\ ${ }^{3}$ Depto. de Genética - USP/ESALQ, C.P. 83 - CEP 13400-970 - Piracicaba, SP. \\ *Corresponding author <damercal@moulon.inra.fr>
}

ABSTRACT: The Opaque-2 (O2) gene encodes a transcriptional activator specifically expressed for grain development of maize. 02 mutants have an opaque and chalky kernel, with a decrease in zein storage protein content, and an increase in the proportions of lysine and tryptophan. In this review, we present recent results investigating genetic properties of the $\mathrm{O} 2$ network, using transcriptome and proteome approaches, associated with measurements of activities of enzymes of the aspartate pathway and lysine degradation. The structural polymorphism at the $\mathrm{O} 2$ locus was investigated by RFLP in a collection of 51 maize inbred lines. Most polymorphic sites were found outside the coding regions. We then searched for relationships between RFLP polymorphism and (i) mRNA abundance of $\mathrm{O} 2$ and of known or suspected target genes, (ii) activity of SDH and (iii) amount of zein isoforms. Polymorphic restriction sites in the 5' upstream regions of the $\mathrm{O} 2$ gene were found associated with $\mathrm{O} 2 \mathrm{mRNA}$ abundance (three sites) and the amount of two $19 \mathrm{kDa} \alpha$-zein isoforms (two sites). One restriction site on the 3' side of the $\mathrm{O} 2$ gene was found associated with Lor/Sdh mRNA abundance. Our results indicate relationships between polymorphism at the $\mathrm{O} 2$ locus and the expression of some of its target genes. Evidence of these associations has to be confirmed on larger samples, and the analysis of the $\mathrm{O} 2$ gene sequence should allow more precise testing of the actual involvement of $\mathrm{O} 2$ polymorphism in its own transcriptional expression, and in the expression of its target genes.

Key words: zein, aspartate kinase, lysine oxoglutarate reductase/saccharopine dehydrogenase, polymorphism

\section{ANÁLISE QUANTITATIVA DE RNA MENSAGEIROS, PROTEÍNAS E ATIVIDADES ENZIMÁTICAS NO ESTUDO DA REDE DE REGULAÇÃO CONTROLADA PELO GENE OPACO-2}

\begin{abstract}
RESUMO: O gene Opaco-2 (O2), expresso especificamente no grão de milho, transcreve para um fator de transcrição da família "leucine-zipper". Mutantes 02 apresentam grãos opacos, redução na quantidade de zeínas e aumento na proporção de lisina e triptofano. Genes cuja expressão é controlada diretamente pelo O2 são conhecidos ( $\alpha$-zeínas de $22 \mathrm{kDa}$, $\beta$-zeínas de $14 \mathrm{kDa}$, b-32 e cyPpdk1). Nesta revisão, nós apresentamos resultados da caracterização genética de genes relacionados com $\circ \mathrm{O} 2$, através de abordagens de transcritoma, proteoma e de atividades enzimáticas da via metabólica do aspartato e da degradação da lisina. O polimorfismo do locus $\mathrm{O} 2$ foi avaliado utilisando-se a técnica de RFLP em 51 linhagens de milho. A maioria dos polimorfismos foi observada nas regiões não codificadoras da proteína. Análises de correlação foram realizadas entre os polimorfismos de RFLP e (i) quantidade de RNAm do O2, cyPpdk, Lor/Sdh e Ahas (ii) quantidade de isoformas de zeínas e (iii) atividade da enzima SDH. Sítios polimórficos foram correlacionados com a quantidade de RNAm do próprio O2, do gene Lor/Sdh e com a quantidade de duas isoformas de azeinas de $19 \mathrm{kDa}$. Nossos resultados indicam a presença de relações entre o polimorfismo do locus $\mathrm{O} 2 \mathrm{e} o$ nível de expressão de genes sob o seu controle. A utilização de um maior número de linhagens e o uso de dados de seqüência do $\mathrm{O} 2$ permitirá uma análise precisa da conseqüência do polimorfismo deste fator de transcrição sobre o controle do seu próprio nível de expressão e dos genes por ele controlados.
\end{abstract}

Palavras-chave: zeína, aspartato quinase, opaco-2, poliformismo

Introduction to the Opaque-2 regulatory network

The recessive opaque-2 (o2) mutation of maize gives an opaque character to the usually translucent mature kernel, but has also many pleiotropic effects. It produces a very marked decrease in alcohol soluble storage protein content $(50-70 \%$ of wild-type depending on the background), while the proportions of lysine and tryptophan are increased in the seed, resulting in an improvement in the nutritional quality. Various aspects of endosperm metabolism are also modified: RNase activity 
is higher in mutant than in wild-type (Dalby \& Davies, 1967), amino acid metabolism, specially aspartate metabolism appeared to be altered (Yunes et al., 1994) as well as the expression of various enzymes related to nitrogen and sugar metabolism (Giroux et al., 1994; Lodha et al., 1974). In some backgrounds, lower levels of carbohydrates were found (Di Fonzo et al., 1979; Murphy \& Dalby, 1971). A reduction in protandry in mutants (Gupta, 1979) and differences in photosynthetic activity of young seedlings (Morot-Gaudry et al., 1979) have been reported. Finally, mutant kernels are more susceptible to plant pathogens than wild-types and yield is decreased (Loesch et al., 1976).

The use of modifier genes has allowed the selection of modified 02 lines that maintain the increased concentrations of lysine and tryptophan in a modifiedvitreous endosperm with a good grain yield (quality protein maize or QPM). Since the development of QPM varieties, several studies have been conducted mainly on the agronomic aspects of the kernel and the plant, such as combining ability for yield and protein quality (Pixley \& Bjarnason, 1993), kernel hardness and density, protein content, increase in $\gamma$-zein storage protein, lysine content (Moro et al., 1995; Paulis et al., 1993), nutritional value (Sullivan et al., 1989) and use in the food industry (Martinez et al., 1996) among others. Also, aspects related to the mapping of 02 modifier genes and their effects on 02 phenotype and protein contents have been studied (Geetha et al., 1991; Lopes \& Larkins, 1995; Lopes et al., 1995).

The $\mathrm{O} 2$ gene was isolated by transposon tagging and was found to encode a transcriptional activator of the basic leucine-zipper family (Hartings et al., 1989; Schmidt et al., 1990). The gene is specifically expressed in the endosperm, as early as 10 days after pollination (Gallusci et al., 1994). The functional O2 protein is a dimer that binds to two different recognition sequences (Yunes et al., 1994) and has an activation domain in a single acidic region located near the $\mathrm{N}$-terminus of the protein (Schmitz et al., 1997).

Two regulatory mechanisms appear to control $\mathrm{O} 2$ abundance/efficiency diurnally. First, it was demonstrated that multiphosphorylated forms of the $\mathrm{O} 2$ protein exist in vivo, the phosphorylation level being crucial for the DNA binding activity: only unphosphorylated or hypophosphorylated forms are able to bind the target DNA sequence with high affinity, and these forms accumulate by day, while hyperphosphorylated forms are predominant at night (Ciceri et al., 1997). Second, the steady state level of the $\mathrm{O} 2$ transcript was subject to diurnal changes, with the highest level of transcript at midday and the lowest level at midnight (Ciceri et al., 1999). The coexistence of different mechanisms of control of $\mathrm{O} 2$ activity suggests that there is an adaptive value for the daily rythmicity in $\mathrm{O} 2$ activity.

The 02 protein was shown to activate the transcription of the $22 \mathrm{kDa} \alpha$-zein (Schmidt et al., 1992) and $14 \mathrm{kDa} \beta$-zein genes (Cord Neto et al., 1995), $b$-32 (Lohmer et al., 1991) and cyPpdk1 (one of two cytosolic isoforms of pyruvate orthophosphate dikinase) genes (Maddaloni et al., 1996). These genes are thus direct targets for O2. In order to complement the list of direct, but also indirect (i.e. not transcriptionally controlled by $\mathrm{O} 2$, but via other genes controlled by 02 ) target genes and gain a better overview of the network controlled by $\mathrm{O} 2$, gene expression was compared in wild-type and mutant o2 near-isogenic lines, at the mRNA level (Habben et al., 1993; Maddaloni et al., ) as well as at the protein level (Damerval \& Le Guilloux, 1998; Habben et al., 1995). Genes whose expression was altered by the mutation belonged to various metabolic pathways, such as glycolysis, amino acid biosynthesis, and the allocation of carbon skeletons between carbohydrate and amino acid synthesis.

The increased amount of lysine in the 02 mutant prompted studies on the biochemical pathway leading to lysine production, namely the pathway derived from aspartate (Azevedo et al., 1997). Aspartate kinase (AK) is the first enzyme of this pathway, leading to lysine, methionine, threonine and isoleucine. The Ask1 gene encodes an AK isoenzyme sensitive to lysine inhibition. The biochemical analysis of a double mutant ask102 indicated alterations in the level of soluble amino acids, total amino acids, storage proteins and enzyme activity suggesting that the ask1 gene may be regulated by $\mathrm{O} 2$ (Azevedo et al., 1990; Brennecke et al., 1996). Furthermore, genetic analysis showed that both genes are linked on chromosome 7 (Azevedo et al., 1990). Recent results suggest that the Ask2 gene that encodes an aspartate kinase sensitive to lysine inhibition could be a QTL for free amino acid content in o2 mutants (Wang \& Larkins, 2001; Wang et al., 2001). However, the question of the control of Ask2 by $\mathrm{O} 2$ remains opened. Evidence has also been obtained that the enzyme dihydrodipicolinate synthase (DHDPS), which is the first enzyme of the lysine branch in the biosynthesis pathway, might be down-regulated by 02 , since the 02 mutant exhibited much higher levels of DHDPS activity in the endosperm as compared to the wild-type (unpublished results, R. Azevedo).

Lysine catabolism is also an important factor for lysine accumulation. The saccharopine pathway is the major route for lysine degradation in plants (Azevedo \& Lea, 2001). The first two enzymatic steps are catalyzed by lysine-oxoglutarate reductase and saccharopine dehydrogenase, as two parts of a bifunctional polypeptide (LOR/SDH). It was shown that the LOR activity was decreased by a factor of 2 to 3 in 02 mutants as compared to wild-types (Brochetto-Braga et al., 1992). The cDNA corresponding to LOR/SDH was sequenced, revealing that the SDH activity was encoded by the Cterminal part of the messenger, while the $\mathrm{N}$-terminal sequence encoded the LOR enzyme (Kemper et al., 1999). In the 02 mutant, the mRNA and protein quantities 
were severely reduced (about $90 \%$ ), and the expression pattern during grain development was markedly modified. The genomic sequence of the gene and its 5' regulatory regions revealed the presence of $\mathrm{O} 2$ boxes in the upstream promoter (Arruda et al., 2000), confirming the hypothesis of a transcriptional control of the Lor/Sdh gene by $\mathrm{O} 2$.

Activities of enzymes of the apartate pathway and lysine catabolism were studied in two QPM, an 02 mutant and a wild-type $\mathrm{O} 2$ varieties. AK activity was higher in the QPM as compared to the wild-type and mutant 02 genotypes, suggesting a mechanism for increased lysine synthesis. In the same way, the LOR and $\mathrm{SDH}$ activities appeared lower in the QPM than in the 02 variety. Thus the modifier genes appeared to enhance the effects of 02 on the LOR/SDH. Both results accounted for a higher level of soluble lysine in QPM varieties as compared to wild-type and o2 genotypes (Gaziola et al., 1999).

The variety of target genes of $\mathrm{O} 2$ thus suggests that this transcriptional activator may play an important role in the developing grain, as a coordinator of the expression of storage protein and nitrogen and carbon metabolism enzyme genes. The $\mathrm{O} 2$ gene together with the genes it controls constitute a network, whose genetic properties is interesting to analyze. Only few gene networks had been studied this way, the most remarkable being the anthocyanin pathway in maize (Rausher et al., 1999). In this paper we review recent results relating the genetic variability of the $\mathrm{O} 2$ structural gene with its own level of expression (mRNA abundance), and the expression of putative or known target genes and enzyme genes of amino acid biosynthesis (RNA abundance, enzyme activities, protein amounts).

\section{RESULTS AND DISCUSSION}

Structural gene polymorphism of $\mathrm{O} 2$ and the expression of several potential target genes were analyzed in a collection of 51 genetically diversified maize lines, with different kernel types (Table 1). The variability of mRNA abundance was analyzed for cyPpdk, Lor/Sdh and the acetohydroxy acid synthase gene (Ahas). AHAS is an enzyme involved in the branched amino acid biosynthetic pathway. Its amount decreased in 02 mutants as compared to their near-isogenic wild-type counterparts (Damerval \& Le Guilloux, 1998), and the mRNA abundance was also decreased in the mutants (Consoli, 2000). Both observations suggest that Ahas could be a direct target gene of $\mathrm{O} 2$.

Variability of enzyme activity was checked for two enzymes of the aspartate pathway, namely aspartate kinase, which is suspected to be under $\mathrm{O} 2$ control (Azevedo et al., 1990), and HSDH, which is involved in the regulation of threonine biosynthesis. The activity of the lysine catabolism enzyme LOR/SDH was also measured.
The variability in amounts of zein isoforms, several of whose encoding genes are regulated by $\mathrm{O} 2$, was appraised after automatic protein spot quantification following two-dimensional electrophoresis (Consoli \& Damerval, 2001)

\section{Structural and expression polymorphism of the $\mathrm{O2}$ gene}

\section{Restriction map of the $\mathrm{O} 2$ locus}

The molecular polymorphism at the $\mathrm{O} 2$ locus was investigated by restriction mapping of genomic DNA in the collection of 51 inbred lines. Forty-two sites and one insertion/deletion (indel) were mapped, of which 35 sites and the indel were polymorphic. Nine sites were found in the coding regions, three of which were polymorphic. Thus most polymorphic sites were outside the coding region, covering up to $\sim 32 \mathrm{~kb}$ in the $5^{\prime}$ upstream regions of the gene, and $14 \mathrm{~kb}$ in the 3 ' downstream regions (Figure 1). The inbred lines grouped into 26 haplotypes. The most frequent one was found in 8 inbred lines, while 16 haplotypes were represented by just one line (Lefèvre, 2000).

Relationships between molecular polymorphism at the $\mathrm{O2}$ locus and $\mathrm{O2}$ transcript abundance

As a first step in investigating the consequences of $\mathrm{O} 2$ polymorphism on its own product efficiency, we analyzed the variability of transcript abundance.

A large genetic variability for 02 mRNA abundance was observed in the collection of inbred lines, at both 15 DAP and 20 DAP (Figure 2). Fifteen polymorphic sites from the $\mathrm{O} 2$ locus map, whose frequency of presence/absence was above 0.05 , were used to check for associations between molecular polymorphism and mRNA abundance in grains at the two developmental stages. Since a large number of tests were performed and they were not independent because of linkage disequilibrium between restriction sites, a permutation test was used to define a threshold for a $5 \%$ experiment wise error for assessing the relationships (Churchill \& Doerge, 1994). Three significant associations were observed at 20 DAP but not at 15 DAP, involving polymorphic sites in the 5 ' upstream regions of the $\mathrm{O} 2$ gene (Figure 1). In order to be sure that the associations revealed are due to the locus under investigation, and not to another locus somewhere else in the genome and in linkage disequilibrium with $\mathrm{O} 2$, a test for long range linkage disequilibrium was performed using one RFLP probe per chromosome arm. No significant linkage disequilibrium was found (D. Manicacci, pers. com.). However, short range linkage disequilibrium is not excluded. As a matter of fact, the three restriction sites associated with 02 mRNA abundance were in strong linkage disequilibrium with each other. It is most probable that these sites, rather than being responsible for the association, are in turn in linkage disequilibrium with the actual involved polymorphism(s), whose precise localisation is presently unknown. 
Table 1 - Collection of 51 maize inbreds.

\begin{tabular}{|c|c|c|c|}
\hline $\begin{array}{c}\text { Genotype } \\
\text { name }\end{array}$ & Kemel type & $\begin{array}{c}\text { Genotype } \\
\text { name }\end{array}$ & Kemel type \\
\hline Co255 & Flint-dent & $\mathrm{F} 277$ & Dent \\
\hline F113 & Dent & F544 & Flint-dent \\
\hline F1852 & Flint-dent & F591 & Flint \\
\hline F2 & Flint & F604 & Dent \\
\hline F252 & Dent & F670 & Flint-dent \\
\hline F268 & Flint & $\mathrm{F} 7$ & Flint \\
\hline $\mathrm{F} 271$ & Dent & F752 & Dent \\
\hline F283 & Flint & W117 & Dent \\
\hline F284 & Dent & W401 & Dent \\
\hline F292 & Dent & $\mathrm{C} 6$ & Dent, pop corn \\
\hline $\mathrm{F} 476$ & Flint-dent & CML239 & Flint \\
\hline F584 & Dent & CML243 & Flint \\
\hline F608 & Dent & CML245 & Flint \\
\hline F618 & Dent & CML246 & Flint \\
\hline F7001 & Flint-dent & CoeSt6 & Floury \\
\hline LH146 & Dent & Fs59 & Flint, floury \\
\hline LH52 & Dent & la5pop & Pop corn \\
\hline LH74 & Dent & Lo32 & Flint, plata \\
\hline LH82 & Dent & ArgL256 & Plata \\
\hline Mbs797 & Dent & W64A & Dent \\
\hline Mbs847 & Dent & Oh43 & Dent \\
\hline A 188 & Dent & B37 & Dent \\
\hline A654 & Dent & $\mathrm{Kn} 1$ & Flint \\
\hline B89 & Dent & Vp1 & Dent \\
\hline CM174 & Dent & Du101 & Flint \\
\hline Co158 & Dent & & \\
\hline
\end{tabular}

Another study was conducted on a Recombinant Inbred Line (RIL) progeny. mRNA abundance in $15 \mathrm{DAP}$ endosperms was measured in each of $121 \mathrm{RILs}$, and QTL detection methodologies allowed 7 QTLs for transcript abundance to be mapped, which explained $52 \%$ of the total genetic variation of the trait (Lefèvre ${ }^{1}$ ). Three QTLs were mapped on chromosome 2, and one on each of chromosomes 1, 3, 4 and 9. Importantly, no QTL was detected in the vicinity of the $\mathrm{O} 2$ locus on chromosome 7. Nevertheless DNA sequence polymorphism did exist between the two parental lines (Henry \& Damerval, 1997, and unpublished). In this descent at least and at this developmental stage, the $\mathrm{O} 2$ sequence polymorphism has no detectable effect on transcript abundance (Lefèvre ${ }^{1}$ ).

The results obtained in the two types of populations shed light on the complexity of $\mathrm{O} 2$ regulation: both cis-acting and trans-acting polymorphic regulators can play a role, and the factors/elements involved might be stage specific. When the trans-acting regulators are preponderant, it can be hypothesized that $\mathrm{O} 2$ is not the key gene for the regulated expression of its downstream target genes. On the contrary, when the cis-acting regulators are preponderant, modulation in $\mathrm{O} 2$ transcript abundance might result in differential expression of the downstream target genes, provided that the variation in mRNA abundance results in variation in protein amount.

\section{Relationships between 02 gene polymorphism and the expression of its target genes}

mRNA abundance of Lor/Sdh, Ahas and cyPpdk

For cyPpdk and Ahas, probes were obtained by PCR amplification using specific primers designed from published sequences (M58656 and X63553 accession number, respectively). A 5' fragment of the cDNA was used as a probe for the $L o r / S d h$ transcript. The relative abundances of cyPpdk, Ahas and Lor/Sdh mRNA from 20 DAP grains were measured in the collection of inbreds, according to the same procedure as for the $\mathrm{O} 2$ gene. One-way analyses of variance with the inbred line as the factor were performed on the mRNA relative abundance, and a significant genetic effect was revealed for every gene $(p<0.01)$. One polymorphic restriction site at the 3 ' end of the $\mathrm{O} 2$ locus was found associated with the variability of Lor/Sdh mRNA abundance (Figure 1, Consoli, 2000). No significant associations were found for the other genes.

\section{Enzyme activity of AK, LOR/SDH and HSDH}

The four enzymatic activities were determined in 20 DAP endosperms of 21 inbred lines of the collection. For AK, line F604 had the highest activity, followed by Coest6, A654 and F2, while the other genotypes essentially exhibited similar levels of activity (Figure $3 \mathrm{~A}$ ). However, when the assay was performed in the presence of lysine and threonine separately and in combination, different patterns were observed among the genotypes suggesting the presence of different isoenzymes. For instance, seven genotypes (F292, Co158, la5pop, F604, A654, F476, B89) exhibited an AK activity predominantly inhibited by lysine, indicating that in these genotypes the isoenzyme sensitive to lysine is the main form (Figure $3 A$ ). The level of lysine inhibition also varied among these genotypes. However, two genotypes appeared to contain an AK predominantly sensitive to threonine (Coest6, Mbs847) (Figure 3A). In the majority of the genotypes AK was more sensitive to inhibition by lysine and threonine together than separately. The distribution of distinct AK isoenzymes is normally related to the requirement for threonine or lysine by the seed. Further control of the flux of carbon is at HSDH and DHDPS, which lead to the threonine and lysine biosynthetic branch of the aspartic pathway, respectively, using the same substrate for their action (Azevedo et al., 1997). In the case of HSDH (Figure 3B), a considerable variation in total activity was observed, with Coest6 and Mbs847 exhibiting the lowest

'Lefèvre A. (INFRA-URGV). Personnel communication, 2002. 


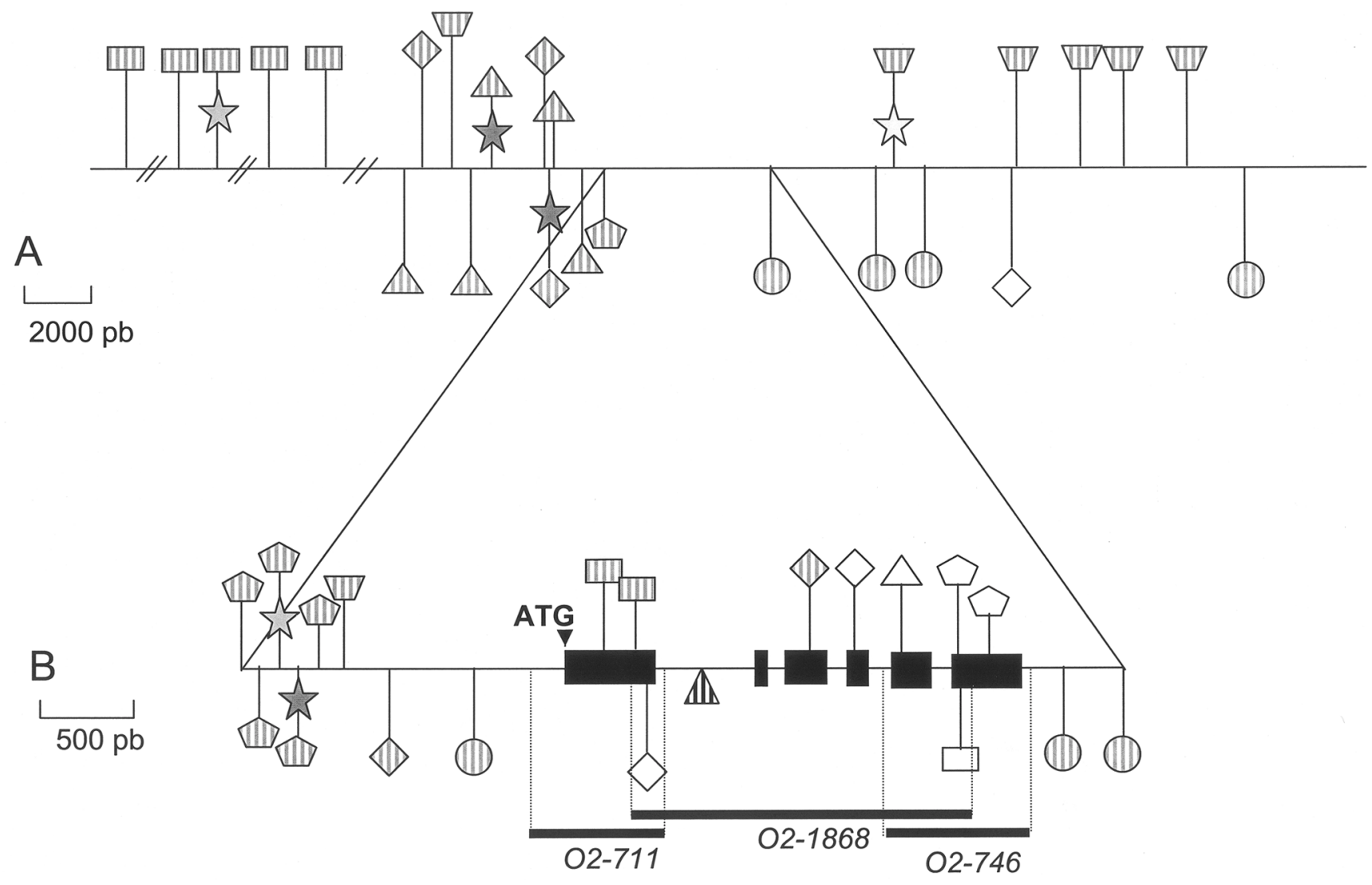

Figure 1 - Restriction map of the $\mathrm{O} 2$ locus showing associations between polymorphic restriction sites and variability of grain traits. Genomic DNA was extracted from young leaves following (Tai \& Tanksley, 1990), and digested with 6 restriction enzymes with a hexanucleotidic recognition site: Narl (rectangles), Xhol (diamond), EcoRI (triangle), EcoRV (trapezoid), Xbal (circle), Sacl (pentagon). Three double digests were also performed (EcoRI+Xbal, EcoRI+EcoRV, EcoRI+Xhol). Three probes covering the whole coding region of the $\mathrm{O} 2$ gene (thick black bars below the gene in B) were labeled by random priming with $50 \mu \mathrm{Ci}\left[{ }^{32} \mathrm{P}\right] \mathrm{dCTP}$ per probe (Feinberg \& Vogelstein, 1983) and used to reveal the restriction fragment length polymorphism. Restriction maps of the locus was obtained for each of the 51 inbred lines, and the polymorphic sites are indicated by the grey stripped symbols (empty symbols for monomorphic sites). The large triangle indicates an indel. B corresponds to enlarged part of the gene encompassing the coding regions (exons as black boxes, introns and non coding regions as a black line) not fully drawn in A. Dark grey stars point to sites associated with $\mathrm{O} 2$ mRNA abundance, medium grey stars are for sites associated with zein amounts, and light grey star is for the site associated with Lor/Sdh mRNA abundance.

$\mathrm{HSDH}$ activity and F2 and A654 the highest one. These results are very interesting since Coest6 and Mbs847 were also shown to have an AK predominantly sensitive to threonine (Figure $3 \mathrm{~A}$ ). These results suggest that carbon flux through the aspartate pathway in these genotypes is under very tight control in the threonine branch, thus possibly favouring the flux of carbon to the lysine branch. It appears that these two genotypes may have a more regulated control over the lysine sensitive AK. Although none of the genotypes exhibited a strong inhibition by threonine, which suggests that the threonine-resistant $\mathrm{HSDH}$ isoenzyme is predominant, the two lines exhibiting the highest levels of HSDH also exhibited the highest threonine inhibition levels (Figure $3 \mathrm{~B}$ ), suggesting the presence of the threonine-sensitive $\mathrm{HSDH}$ isoenzyme.

For LOR and SDH, the genotypes were analysed by the spectrophotometer assay and in the case of SDH, also by activity staining on non-denaturing PAGE. A significant genetic effect was observed for SDH activity only, probably because of the high variation within some genotypes for LOR activity (Figure 4). The highest levels of LOR activity were observed for F284, la5pop, Coest6 and F604, indicating that the rate of lysine degradation is probably higher in these genotypes. Particularly interesting is the result for Coest6, since this genotype appeared to favour lysine biosynthesis when AK and $\mathrm{HSDH}$ were analysed. The result for LOR confirmed such a possibility, since a higher level of lysine being synthesised would lead to an increase in lysine degradation, which is the case for Coest6.

The mRNA abundance of Lor/Sdh did not appeared to be significantly correlated with the SDH activity. In 02 mutants as compared to wild-type, the activities of LOR and SDH at 20 DAP were reduced to $\sim 2$ and $18 \%$ respectively, while the abundance of transcript was in turn reduced to $90 \%$. Complex processes (e.g. phosphorylation) taking place between transcription and maturation of the enzymes certainly 
explain this result (Kemper et al., 1999). Possible genetic variability on these processes would account for the lack of correlation that we observed in unrelated genotypes. Consistently, a test for association between variability in SDH activity and the polymorphism of restriction sites at the $\mathrm{O} 2$ locus did not produce significant associations.

\section{Zein amount}

Zeins are the major storage proteins of the maize grain, accounting for more than $70 \%$ of the total proteins at maturity. They are largely responsible for the poor nutritive value of the kernel, due to their lack of lysine and very low level of tryptophan. They are divided in four families $(\alpha, \beta, \gamma, \delta)$ based on DNA sequence similarity (Rubenstein \& Geraghty, 1986). The $\alpha$-zeins and the $\gamma$ zeins are further subdivided into two subfamilies each, according to polypeptide molecular mass as observed on one-dimensional SDS-PAGE electrophoregrams ( $\alpha 22$ $\mathrm{kDa}$ and $\alpha 19 \mathrm{kDa}$ zeins, $\gamma 27 \mathrm{kDa}$ and $\gamma 16 \mathrm{kDa}$ zeins).

Fifty-nine isoforms of the various families of zeins were separated by 2-D PAGE and their amount was quantified from Coomassie blue stained gels in 45 inbred lines of the collection, and in one 02 mutant (Consoli \& Damerval, 2001). The well-known effect of the mutation was observed on $\alpha 22 \mathrm{kDa}$ zeins. Nine allelic variations were detected among the inbred lines. Considering the allelic spots as the same protein, only 6 isoforms were common to all lines, pointing to the large qualitative variability of zeins. A highly significant genetic effect $(P<0.01)$ was detected for 31 isoforms out of 42
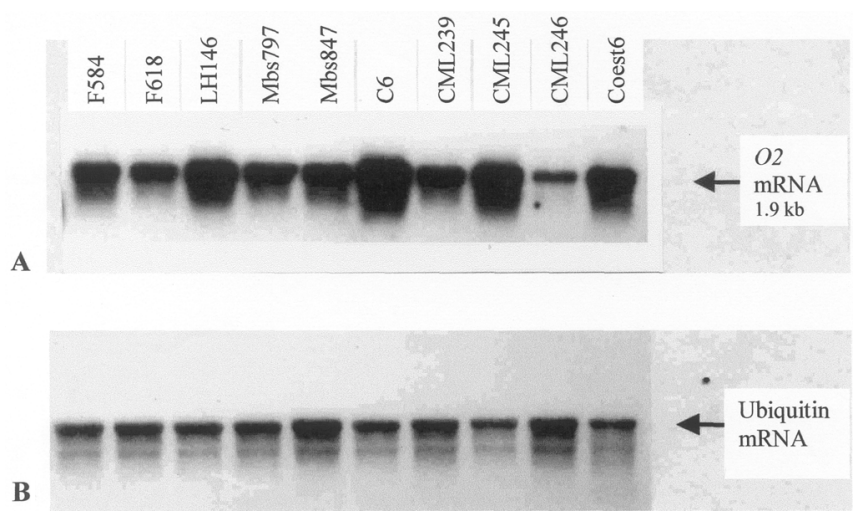

Figure 2 - Variability in 02 mRNA abundance in grains at 15 DAP in a subset of inbred lines. Total RNA was isolated by a phenol-chlorofom extraction followed by a lithium chloride precipitation as described by (Bartels \& Thompson, 1983) and (De Vries et al., 1982). A. Northern blot hybridized with a ${ }^{32} \mathrm{P}$ labeled fragment of $746 \mathrm{bp}$ specific of $\mathrm{O} 2$ (Figure1). Northern blots were revealed using a Phosphorlmager (Molecular Dynamics). The signal was quantified by the Image Quant v.3 software. To compensate for possible differences in total RNA amount between samples, the filters were stripped and reprobed with the constitutively expressed maize ubiquitin gene (B). The 02 signal was divided by the value of the ubiquitin signal in every repeat of every inbred line. At least four repeats were run per inbred line (see Lefèvre 2000 for details). quantitatively analyzed (74\%), and a non significant effect was observed for only 5 isoforms that were present in a limited number of lines.

The 15 polymorphic sites from the $\mathrm{O} 2$ restriction map that had previously been used to test associations with mRNA abundance, were used to check for associations with (i) variation in the amount of 28 zein isoforms detected in at least 10 among the 45 inbreds, (ii) total zein content extracted at maturity using a simplified Landry \& Moureaux procedure (Landry et al., 2000) and then determined using a colorimetric ninhydrin assay (Landry \& Delhaye, 1996), (iii) amount of total protein in the mature grain determined by the ninhydrin assay. On the one hand, no associations appeared significant for total protein, total zein, and $\alpha 22 \mathrm{kDa}$ zein and $\beta$-zein amounts. These latter two zein families are encoded by known target genes of the $\mathrm{O} 2$ transcriptional activator. The lack of association with $\mathrm{O} 2$ polymorphism may reside in two different causes: (i) the effect, if any, of $\mathrm{O} 2$ polymorphism on zein gene transcription and zein accumulation is no longer apparent at grain maturity; (ii) the pertinent polymorphism may be within the coding sequence, and
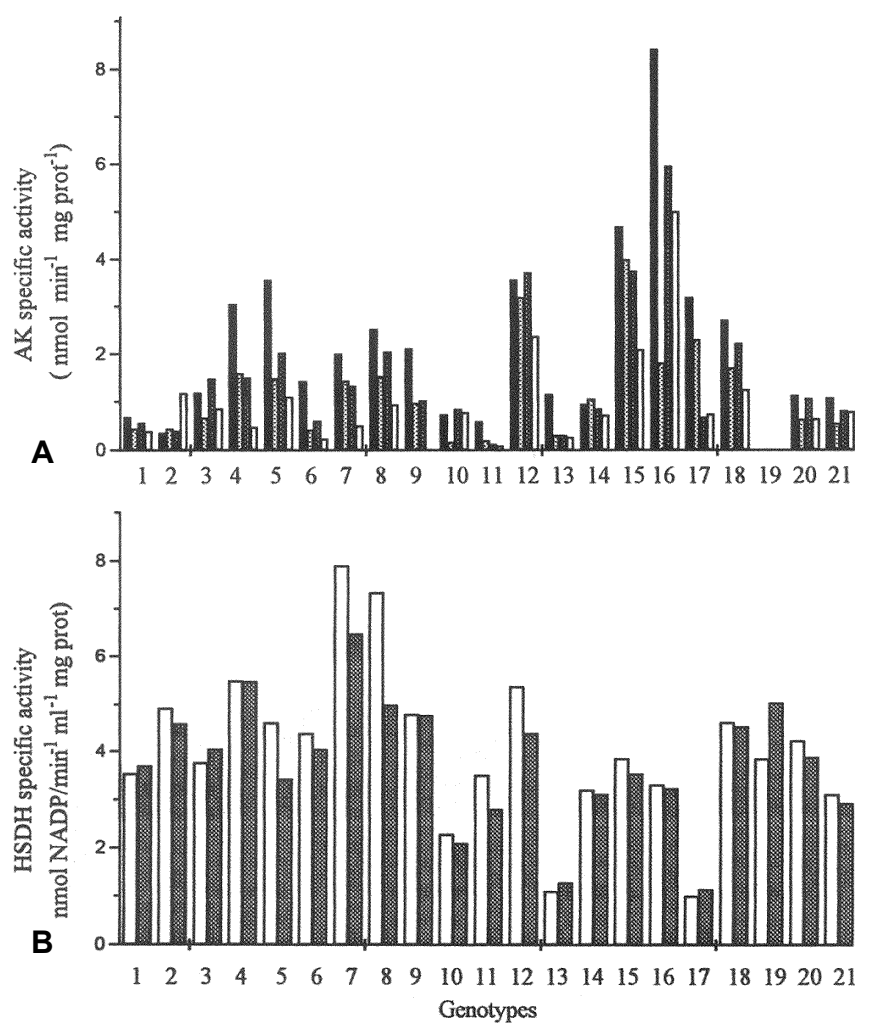

Figure $3-\mathrm{AK}(\mathbf{A})$ and HSDH (B) specific activities of 20 DAP maize endosperm. la5pop (1), Co255 (2), B 89 (3), Lo32 (4), F252 (5), LH 74 (6), F2 (7), A654 (8), Mbs797 (9), F292 (10), F113 (11), F7 (12), Mbs847 (13), LH82 (14), LH146 (15), F604 (16), Coest6 (17), F544 (18), F284 (19), F476 (20), Co158 (21). In (A), bars from left to right represent control activity, plus $5 \mathrm{~m} \mathrm{M}$ threonine, plus $5 \mathrm{mM}$ lysine and plus $5 \mathrm{mM}$ lysine plus threonine, respectively. In (B), bars from left to right represent control activity and plus $5 \mathrm{mM}$ threonine. Enzyme activities are expressed in nmol. $\mathrm{min}^{-1} \mathrm{mg}^{-1}$ protein 

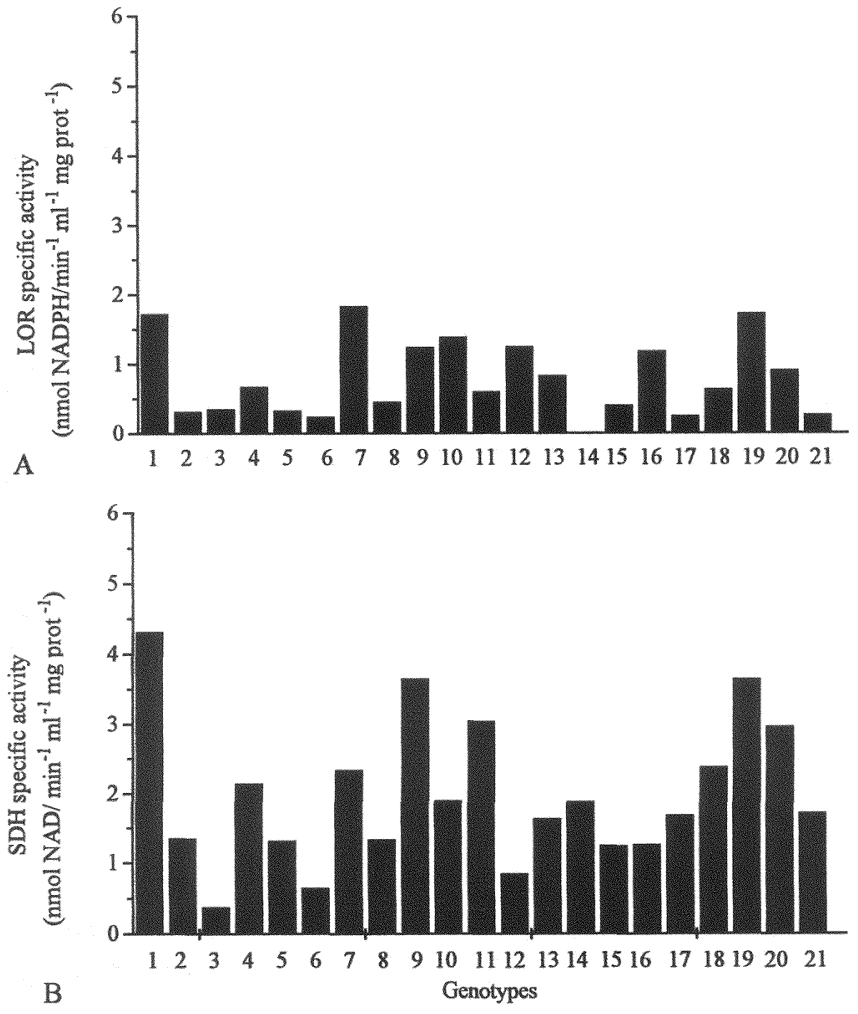

Figure 4 - LOR (A) and SDH (B) specific activities (nmoL NADPH/ NAD min $^{-1} \mathrm{mg}^{-1}$ protein) of 20 DAP maize endosperm. la5pop (1), Co255 (2), B89 (3), Lo32 (4), F252 (5), LH74 (6), F2 (7), A654 (8), Mbs797 (9), F292 (10), F113 (11), F7 (12), Mbs847 (13), LH82 (14), LH146 (15), F604 (16), Coest6 (17), F544 (18), F284 (19), F476 (20), Co158 (21).

was not revealed by the restriction map. On the other hand, two sites upstream of the coding region (-1638bp and $-19128 \mathrm{bp}$ from the ATG, respectively) were found associated with the variation in amount of two different 19 $\mathrm{kDa}$ isoforms (Figure 1). The general value of the two associations found can be questioned because of the low number of genotypes effectively used for the test, due to missing data at restriction sites and qualitative variability of zeins ( 5 and 9 genotypes used, respectively). As for the associations with mRNA abundance, the polymorphisms that are actually responsible remain unknown. The analysis of the $\mathrm{O} 2$ coding gene sequence would allow more precise tests of the relationship between structural polymorphism and the storage protein variability (Lefèvre ${ }^{2}$ )

\section{CONCLUSION}

The results reported here give interesting clues on the genetic properties of a regulatory network. The approach takes into account several levels of the genetic complexity, from DNA polymorphism to protein amount variability, and also variability in enzyme activities. The aim is to dissect the part of the polymorphism at each level of the network that can be explained by the polymorphism at the level(s) below. The differential contribution of these polymorphisms to the variability of

${ }^{2}$ Lefèvre A. (INFRA-URGV). Personnel communication, 2002. more complex phenotypical traits could thus be examined, providing a better understanding of the genetic bases of grain phenotype variation that could be used to improve nutritional value of grain varieties. Our results have to be confirmed on a larger collection of inbred lines, and the associations between $\mathrm{O} 2$ locus polymorphism and the variability in expression of some of its target genes (zeins, LOR/SDH) should be refined by taking into account the $\mathrm{O} 2$ sequence polymorphism.

\section{ACKNOWLEDGEMENTS}

This project was partly sustained by a collaborative USP-COFECUB program in 1999 and 2000. L. C. received a PhD fellowship from CAPES, Brazil. We also thank Prof. Peter J. Lea (Lancaster University, U.K.) for critical review of this manuscript.

\section{REFERENCES}

ARRUDA, P.; KEMPER, E.L.; PAPES, F.; LEITE, A. Regulation of lysine catabolism in higer plants. Trends in Plant Science, v.5, p.324-330, 2000. AZEVEDO, R.A.; ARANA, J.L.; ARRUDA, P. Biochemical genetics of the interaction of the lysine plus threonine resistant mutant $L \operatorname{tr}^{*} 1$ with opaque2 maize mutant. Plant Science (Limerick), v.70, p.81-90, 1990.

AZEVEDO, R.A.; ARRUDA, P.; TURNER, W.L.; LEA, P.J. The biosynthesis and metabolism of the aspartate derived amino acids in higher plants. Phytochemistry, v.46, p.395-419, 1997.

AZEVEDO, R.A.; LEA, P.J. Lysine metabolism in higher plants. Amino Acids V.20, p.261-279, 2001

BARTELS, D.; THOMPSON, R.D. The characterization of cDNA clones coding for wheat storage proteins. Nucleic Acids Research, v.11, p.2961-2978, 1983.

BRENNECKE, K.; SOUZA NETO, A.J.; LUGLI, J.; LEA, P.J.; AZEVEDO, R.A. Aspartate kinase in the maize mutants ask1-It19 and opaque-2. Phytochemistry, v.41, p.707-712, 1996.

BROCHETTO-BRAGA, M.R.; LEITE, A.; ARRUDA, P. Partial purification and characterization of lysine-ketoglutarate reductase in normal and opaque2 maize endosperms. Plant Physiology, v.98, p.1139-1147, 1992.

CHURCHILL, G.A.; DOERGE, R.W. Empirical threshold values for quantitative trait mapping. Genetics, v.138, p.963-971, 1994

CICERI, P.; GIANAZZA, E.; LAZZARI, B.; LIPPOLI, G.; GENGA, A.; HOSCHEK, G.; SCHMIDT, R.J.; VIOTTI, A. Phosphorylation of Opaque2 changes diurnally and impacts its DNA binding activity. Plant Cell, v.9, p.97-108, 1997

CICERI, P.; LOCATELLI, F.; GENGA, A.; VIOTTI, A.; SCHMIDT, R.J. The activity of the maize Opaque2 transcriptional activator is regulated diurnally. Plant Physiology, v.121, p.1321-1327, 1999.

CONSOLI, L. Analyse de la variabilité d'expression et de structure de gènes cibles du facteur de transcription Opaque-2 chez le maïs (Zea mays L.) Recherche d'associations avec le polymorphisme du locus O2. Orsay, 2000. 94p. Thesis (Ph.D.) - Université Paris XI.

CONSOLI, L.; DAMERVAL, C. Quantification of individual zein isoforms resolved by two-dimensional electrophoresis: Genetic variability in 45 maize inbred lines. Electrophoresis, v.22, p.2983-2989, 2001.

CORD NETO, G.; YUNES, J.A.; DASILVA, M.J.; VETTORE, A.L.; ARRUDA, P.; LEITE, A. The involvement of Opaque 2 on beta-prolamin gene regulation in maize and Coix suggests a more general role for this transcriptional activator. Plant Molecular Biology, v.27, p.1015-1029, 1995.

DALBY, A.; DAVIES, II. Ribonuclease activity in the developing seeds of normal and opaque-2 maize. Science, v.155, p.1573-1575, 1967.

DAMERVAL, C.; LE GUILLOUX, M. Characterization of novel target proteins of the 02 mutation expressed duringmaize endosperm development. Molecular and General Genetics, v.257, p.354-361, 1998.

DE VRIES, S.C.; SPRINGER, J.; WESSELS, J.G.H. Diversity of abundant mRNA sequences and patterns of protein synthesis in etiolated and greened pea seedlings. Planta, v.156, p.129-135, 1982.

DI FONZO, N.; GENTINETTA, E.; SALAMINI, F. Action of the opaque-7 mutation on the accumulation of storage products in maize endosperm. Plant Sciences Letters, v.14, p.345-354, 1979. 
FEINBERG, A.P.; VOGELSTEIN, B. A technique for radiolabeling DNA restriction endonuclease fragments to high specific activity. Analytical Biochemistry, v.132, p.6-13, 1983.

GALLUSCI, P.; SALAMINI, F.; THOMPSON, R.D. Differences in cell typespecific expression of the gene Opaque 2 in maize and transgenic tobacco. Molecular and General Genetics, v.244, p.391-400, 1994.

GAZIOLA, S.A.; ALESSI, E.S.; GUIMARAES, P.E.O.; DAMERVAL, C.; AZEVEDO, R.A. Quality protein maize: a biochemical study of enzymes involved in lysine metabolism. Journal of Agricultural and Food Chemistry, v.47, p.1268-1275, 1999.

GEETHA, K.B.; LENDING, C.R.; LOPES, M.A.; WALLACE, J.C.; LARKINS B.A. Opaque-2 modifiers increase gamma -zein synthesis and alter its spatial distribution in maize endosperm. Plant Cell, v.3, p.1207-1219, 1991.

GIROUX, M.J.; BOYER, C.; FEIX, G.; HANNAH, L.C. Coordinated transcriptional regulation of storage product genes in the maize endosperm. Plant Physiology, v.106, p.713-722, 1994.

GUPTA, D. Shortening of protandry by opaque-2 mutant gene. Indian Journal of Genetics and Plant Breeding, v.39, p.230-233, 1979.

HABBEN, J.E.; KIRLEIS, A.W.; LARKINS, B.A. The origin of lysine-containing proteins in opaque-2 maize endosperm. Plant Molecular Biology, v.23, p.825-838, 1993.

HABBEN, J.E.; MORO, G.L.; HUNTER, B.G.; HAMAKER, B.R.; LARKINS, B.A. Elongation factor 1 a concentration is highly correlated with lysine content of maize endosperm. Proceedings of the National Academy of Sciences of the USA, v.92, p.8640-8644, 1995.

HARTINGS, H : MADDALONI, M. LAZZARONI, N - FONZO, N.D. MOTTO, M.; SALAMINI, F.; THOMPSON, R. The O2 gene which regulates zein deposition in maize endosperm encodes a protein with structural homologies to transcriptional activators. EMBO Journal, v.8, p.2795-2801, 1989.

HENRY, A.M.; DAMERVAL, C. High rates of polymorphism and recombination at the Opaque-2 locus in cultivated maize. Molecular and General Genetics, v.256, p.147-157, 1997.

KEMPER, E.L.; CORD NETO, G.; PAPES, F.; MARTINEZ MORAES, K.C.; LEITE, A.; ARRUDA, P. The role of Opaque2 in the control of lysinedegrading activities in developing maize endosperm.Plant Cell, v.11, p.1981-1993, 1999.

LANDRY, J.; DELHAYE, S. A simple and rapid procedure for hydrolyzing minute amounts of proteins with alkali. Analytical Biochemistry, v.243, p.191194, 1996.

LANDRY, J.; DELHAYE, S.; DAMERVAL, C. Improved method for isolating and quantitating a-amino nitrogen as nonprotein, true protein, salt-soluble proteins, zeins, and true glutelins in maize endosperm. Cereal Chemistry, v.77, p.620-626, 2000

LEFEVVE, A. Analyse du polymorphisme du gène Opaque-2 chez le maïs (Zea mays L.) et recherche de facteurs génétiques impliqués dans la variation de son transcrit. Paris, 2000. 87p. Thesis (Ph.D.) - Université Paris VI.

LODHA, M.L.; MALI, P.C.; AGARWAL, A.K.; MEHTA, S.L. Changes in soluble protein and isoenzymes in normal and opaque-2 Zea mays endosperm during grain development. Phytochemistry, v.13, p.539-542, 1974

LOESCH JR., P.J.; FOLEY, D.C.; COX, D.F. Comparative resistance of Opaque-2 an Normal inbred lines of maize to ear-rotting pathogens. Crop Science, v.16, p.841-842, 1976.

LOHMER, S.; MADDALONI, M.; MOTTO, M.; DIFONZO, N.; HARTINGS, H. SALAMINI, F.; THOMPSON, R.D. The maize regulatory locus Opaque-2 is inhibited by upstream open reading frames present in the leader sequence. Embo Journal, v.10, p.617-624, 1991.

LOPES, M.A.; LARKINS, B.A. Genetic analysis of opaque2 modifier gene activity in maize endosperm. Theoretical and Applied Genetics, v.19, p.274-281, 1995.

LOPES, M.A.; TAKASAKI, K.; BOTSWICK, D.E.; HELENTJARIS, T.; LARKINS, B. A. Idnetification of two opaque2 modifier loci in quality Protein Maize. Molecular and General Genetics, v.247, p.603-613, 1995.
MADDALONI, M.; DONINI, G.; BALCONI, C.; RIZZI, E.; GALLUSCI, P.; FORLANI, F.; LOHMER, S.; THOMPSON, R.; SALAMINI, F.; MOTTO, M. The transcriptional activator Opaque-2 controls the expression of a cytosolic form of pyruvate orthophosphate dikinase-1 in maize endosperms. Molecular and General Genetics, v.250, p.647-654, 1996.

MADDALONI, M.; DONINI, G.; THOMPSON, R.; MOTTO, M. Role of Opaque2 in the shikimate pathway in maize endosperm. Maize Genetics Cooperation Newsletter, v.73, p.13-14, 1999.

MARTINEZ, B.F.; FIGUEROA, J.D.C.; LARIOS, S. A. High lysine extruded products of quality protein maize. Journal of the Science of Food and Agriculture, v.71, p.151-155, 1996.

MORO, G.L.; LOPES, M.A.; HABBEN, J.E.; HAMAKER, B.R.; LARKINS, B.A. Phenotypic effects of opaque2 modifier genes in normal maize endosperm. Cereal Chemistry, v.72, p.94-99, 1995.

MOROT-GAUDRY, J.-F.; FARINEAU, J.; JOLIVET, E. Effect of leaf position and plant age on photosynthetic carbon metabolism in leaves of 8 and 16 day-old maize seedlings (W64A) with and without the gene opaque 2 . Photosynthetica, v.13, p.365-375, 1979

MURPHY, J.J.; DALBY, A. Changes in the protein fractions of developing normal and opaque-2 maize endosperm. Cereal Chemistry, v.48, p.336349, 1971

PAULIS, J.W.; PEPLINSKI, A.J.; BIETZ, J.A.; NELSEN, T.C.; BERGQUIST, R.R. Relation of kernel hardness and lysine to alcohol-soluble protein composition in quality protein maize hybrids. Journal of Agricultural and Food Chemistry, v.41, p.2249-2253, 1993.

PIXLEY, K.V.; BJARNASON, M.S. Combining ability for yield and protein quality among modified-endosperm opaque-2 tropical maize inbreds. Crop Science, v.33, p.1229-1234, 1993.

RAUSHER, M.; MILLER, R.; TIFFIN, P. Patterns of evolutionary rate variation among genes of the anthocyanin biosynthetic pathway. Molecular Biology and Evolution, v.16, p.266-274, 1999.

RUBENSTEIN, I.: GERAGHTY, D.E. The genetic organization of zein Advances in Cereal Science and Technology, v.8, p.297-315, 1986.

SCHMIDT, R.J.; BURR, F.A.; AUKERMAN, M.J.; BURR, B. Maize regulatory gene opaque-2 encodes a protein with a "leucine-zipper" motif that binds to zein DNA. Proceedings of the National Academy of Sciences of the United States of America, v.87, p.46-50, 1990.

SCHMIDT, R.J.; KETUDAT, M.; AUKERMAN, M.J.; HOSCHEK, G. Opaque-2 is a transcriptional activator that recognizes a specific target site in $22-\mathrm{kD}$ zein genes. Plant Cell, v.4, p.689-700, 1992.

SCHMITZ, D.; LOHMER, S.; SALAMINI, F.; THOMPSON, R.D. The activation domain of the maize transcription factor Opaque-2 resides in a single acidic region. Nucleic Acids Research, v.25, p.756-763, 1997.

SULLIVAN, J.S.; KNABE, D.A.; BOCKHOLT, A.J.; GREGG, E.J. Nutritional value of quality protein maize and food corn for starter and growth pigs. Journal of Animal Science, v.67, p.1285-1292, 1989.

TAI, T.H.; TANKSLEY, S.D. A rapid and inexpensive method for isolation of total DNA from dehydrated plant tissues. Plant Molecular Biology Reporter, v.8, p.297-303, 1990.

WANG, X.; LARKINS, B.A. Genetic analysis of amino acid accumulation in opaque-2 maize endosperm. Plant Physiology, v.125, p.1766-1777, 2001.

WANG, X.: STUMPF, D.K.; LARKINS, B.A. Aspartate kinase 2. A candidate gene of a quantitative trait locus influencing free amino acid content in maize endosperm. Plant Physiology, v.125, p.1778-1787, 2001.

YUNES, J.A.; CORD NETO, G.; SILVA, M.J.D.; LEITE, A.; OTTOBONI, L.M.M.; ARRUDA, P. The transcriptional activator Opaque2 recognizes two different target sequences in the 22-kD-like alpha -prolamin genes. Plant Cell, v.6, p.237-249, 1994

Received September 02, 2001 